\title{
SCOTER MIGRATION IN SOUTHEASTERN MANITOBA, 1975-1986
}

PETER TAYLOR, P.O. Box 597, Pinawa, Manitoba ROE 1 L0 and RUDOLF F. KOES, 135 Rossmere Crescent, Winnipeg, Manitoba. R2K 0G1

The status of scoters in Manitoba is poorly understood, because these ducks occur mainly in thinly populated parts of the province. Substantial numbers of all three species occur in the Churchill region, but they do not appear to be common anywhere inland. ${ }^{11}$

The published breeding range of the White-winged Scoter includes nearly all of the province, but this species has declined drastically in southern Manitoba and neighboring North Dakota. ${ }^{15617} \mathrm{As}$ recently as 1974, David Hatch found seven nests at Oak Lake, in southwestern Manitoba, but it is doubtful whether any now nest south of the forested regions of the province. ${ }^{6}$ Bellrose cites an estimated Manitoba population of 27,000 scoters, nearly all White-winged, of which almost $90 \%$ occur on lakes in the boreal forest region, and $7 \%$ in the Saskatchewan River delta.

The other two scoters have probably not bred in southern Manitoba in historic times. The Surf Scoter's nesting range is believed to include much of the open boreal forest region of northern Manitoba. ${ }^{15}$ Faanes recently reported a brood near Churchill. ${ }^{3}$ The Black Scoter's nesting range is disjunct and poorly known, but is thought to include northeastern Manitoba and adjacent Ontario. ${ }^{1}$ ${ }^{16}$ Many thousands moult along the coast of James and Hudson Bays. ${ }^{16}$

Since most scoters migrate directly from their breeding range or moulting areas to either the Atlantic or Pacific coast, they are scarce migrants in the southern Prairie Provinces. ${ }^{5}$ Banding returns for White-winged
Scoters, reported by Houston and Brown, indicate that central Saskatchewan lies on the "migration divide" between populations wintering on the two coasts. ${ }^{10}$

As recently as 1978, both Surf and Black scoters were classed as occasional ("From 6 to 12 confirmed observations since $\left.1945^{\prime \prime}\right)$ in southeastern Manitoba. ${ }^{2}$ Most of these records occurred between 1975 and 1977, causing speculation that these two species may be regular fall migrants in southern Manitoba. ${ }^{12}$ Thompson's accounts of their status in Manitoba in the 19th century are, unfortunately, ambiguous. ${ }^{19}$

\section{Scope of this report}

This analysis includes 150 scoter records from southeastern Manitoba (as defined in the map in fig. 1) from 1975 to 1986 . These sightings are by both Taylor and Koes as well as others which were reported to Koes. Sightings for which observers are not given are referable to one or both of the authors, often in company with other observers. Records prior to 1975 are included only when they occurred outside the extreme migration dates of the period being analysed.

The records total 575 birds, of which about $30 \%$ are believed to be repeat sightings of the same individuals on different days. The overall breakdown by species is 9\% Black (51), 25\% Surf (141) and $66 \%$ White-winged (383). Dates are summarized for each species in Table 1. Sixty-six percent of these sightings occurred at Natalie Lake, which is the forebay of Seven Sisters dam on the Winnipeg River. Most of the remainder were 
at the southern ends of Lakes Manitoba and Winnipeg ( $9 \%$ each) and at Oak Hammock Marsh (8\%; fig. 1). The preponderance of records at Natalie Lake arises partly from intensive coverage by Taylor ( two or three visits per week in May and October since 1978), but this location does seem to be specially favoured by scoters, as well as other migrating water birds. ${ }^{18}$

Nearly all groups of scoters consisted of only one species, except for a few single male Surfs associating with flocks of
White-winged in spring. On the few occasions when flocks of both species were seen in the same general area, they remained as distinct groups, while mingling with large aggregations of scaup and other waterfowl. Information on the size of scoter groups is also summarized (Table 2).

\section{Black Scoter}

This is the least common scoter in southeastern Manitoba. There is only one spring record: George Holland saw two males at Oak Hammock Marsh, 23 April

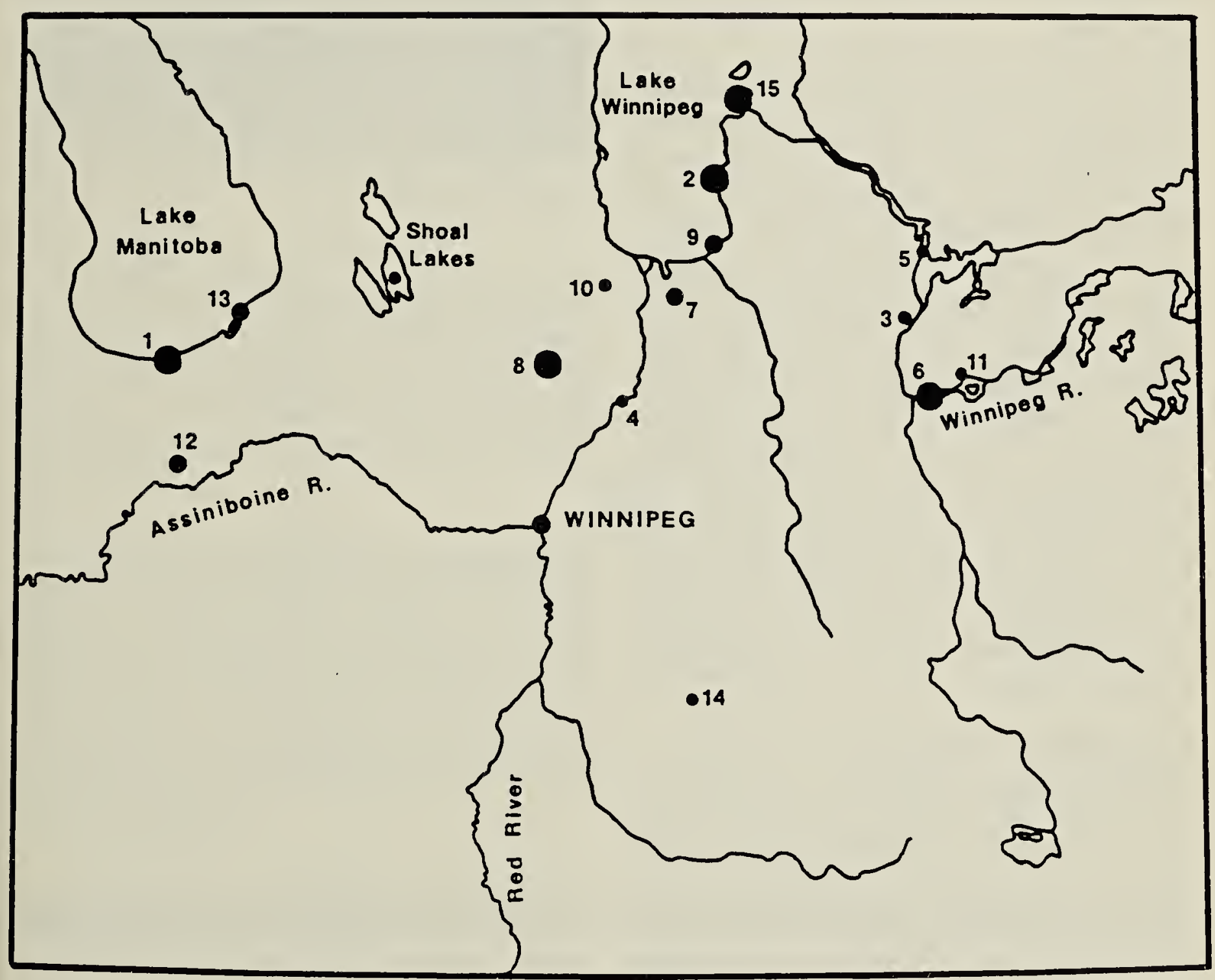

Figure 1. Distribution of scoter sightings in southeastern Manitoba, 1975-1986. Numbered locations (species initials in parentheses): 1 Delta $(B, S, W) ; 2$ Grand Beach and Grand Marais $(B, S, W) ; 3$ Lac du Bonnet (S,W); 4 Lockport (S); 5 McArthur Falls (W); 6 Natalie Lake $(B, S, W) ; 7$ Netley-Libau Marshes $(B, S, W) ; 8$ Oak Hammock Marsh $(B, S, W)$; 9 Patricia Beach $(W) ; 10$ Petersfield $(W) ; 11$ Pinawa $(B, S) ; 12$ Portage la Prairie $(S, W) ; 13$ St. Ambroise $(B, S, W) ; 14$ Steinbach $(S) ; 15$ Victoria Beach $(B, S)$. Small circles 1 or 2 records (includes East Shoal Lake -W). Medium circles 3-5 records (includes Winnipeg - S, W.) Large circles $6+$ records. 
$1975^{4}$ In contrast, there are 23 fall records (49 birds), from every year of the study except 1983 and 1985. Most were seen in October; extreme dates are 25 September 1979 and 19 November 1977. The highest counts were five at Libau 17 Oc- tober 1981 John Christie and L. Simmons), a group of four at Victoria Beach 12-19 November 1977, and four scattered birds at Natalie Lake 21 October 1984. All individuals that could be determined were females or immature males.

Table 1. NUMBERS OF SCOTERS SEEN BY SPECIES AND DATE (Scoter-days, including repeat sightings)

Time Period

21-30 April

1-10 May

11-20 May

21-31 May

1-10 June

11-20 June

TOTAL SPRING

21-31 August

1-10 September

11-20 September

21-30 September

1-10 October

11-20 October

21-31 October

1-10 November

11-20 November

21-30 November

TOTAL FALL

* Reported only as April.

\section{Black Scoter}

2

0

0

0

0

0

2

0

0

0

1

6

13

15

1

13

0

49

\section{Surf Scoter}

$1^{*}$

2

3

8

2

0

16

0

1

0

2

81

33

4

2

2

0

125
White-winged Scoter

5

38

121

20

9

2

195

1

0

0

0

0

80

86

19

1

1

188

Table 2. NUMBERS OF SIGHTINGS OF SCOTERS, BY SPECIES AND GROUP SIZE

Group Size

Black Scoter

Surf Scoter

White-winged

Scoter
Spring

Fall

Spring

Fall

Spring

Fall
1-2

1

15

3-5

0

8

\section{9}

20

19

17
6-10

$11-20$

0

0

0

2

5

3 


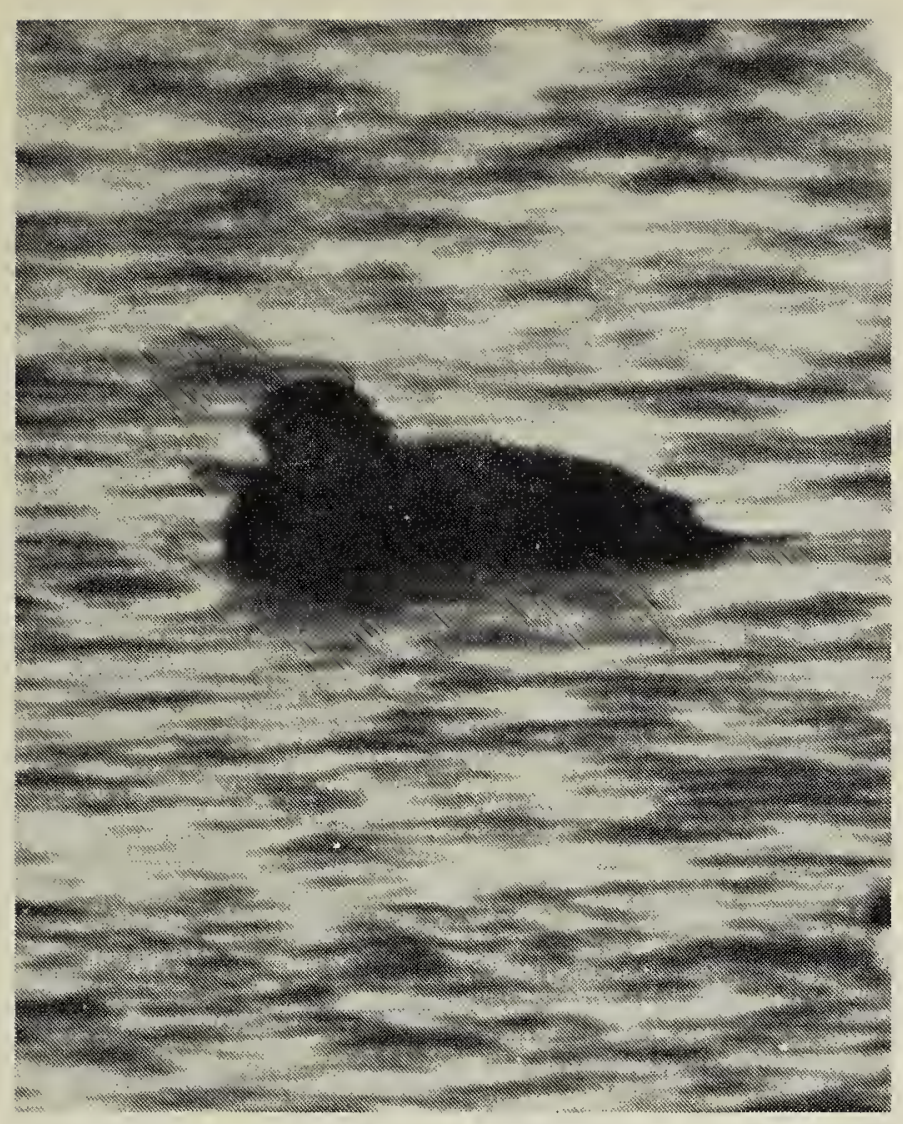

Black Scoter

Fred Lahrman

\section{Surf Scoter}

This species is more common than the Black Scoter, but it also is seen much less frequently in spring (16 birds) than fall (125). It was recorded in six of the 12 springs and each fall except 1976, 1981 and 1986.

Except for a male seen in Winnipeg by John L. Wylie in April 1980, all spring birds were on the Winnipeg River. Two males were near Lac du Bonnet 4 June 1983 and a flock of five, including one adult male, was at Natalie Lake on 26 May 1985. The remainder were all single males at Natalie Lake.

Extreme fall migration dates are 4 September 1977 and 19 November 1977, with a well-defined peak in the first half of October (Table 1). The majority $(88 \%)$ were seen between 1982 and 1985. A concentration at Natalie Lake 1-17 October 1985 accounted for over half the observations (67 birds). The maximum count was 17 , including four adult males, on 3 October. Excluding these four, and a few other 1985 sightings, all fall Surf Scoters were females or immature males.

\section{White-winged Scoter}

This species accounts for over $90 \%$ of spring scoter records, but it is by no means common. Over $80 \%$ of these spring sightings were at Natalie Lake, where White-wingeds were seen each spring from 1978 to 1986 except 1981. There are several records of 10 or more birds, with a maximum of 20 on 13 May 1978 (Gordon Grieef). Spring records elsewhere include 15 at Oak Hammock Marsh 16 May 1976 (Ken Gardner) and 8 at Delta 15 May 1982 (Calvin Cuthbert, lan Ward). Adult males predominate (about $80 \%$ ) in these spring flocks; some birds appear to be paired.

Extreme migration dates are 24 April 1986 (two at Natalie Lake, Wayne Neily, Robert Parsons) and 19 June 1982 (one at Oak Hammock Marsh, David Hatch). There is a well-defined peak in mid-May (Table 1). These observations are consistent with Hochbaum's summary of arrival dates at Delta between 1939 and 1954: once between 21 and 28 April, four times between 29 April and 6 May, and 10 times between 7 and 14 May, making it the latest duck to arrive on average. ${ }^{8}$ The White-winged Scoter bred regularly at Delta until the late 1950 s. ${ }^{9} \mathrm{~A}$ very early arrival 14 April 1926 was reported by $\mathrm{H}$. Battersby at Oak Lake in southwestern Manitoba. ${ }^{14}$

Unlike the other two species, spring and fall sightings of White-winged Scoters are almost equal (Table 1). Fall records are rather more scattered however, and observations at Natalie Lake are less predominant than in spring. The distribution of flock sizes is similar to spring (Table 2). The highest count was 18 at Natalie Lake 21 October 1984.

White-winged Scoters tend to migrate in fall a little later than Surf Scoters, peaking in the second half of October (Table 1). They are not normally seen before midOctober. A single male at McArthur Falls 27 August 1983 was, therefore, unusual. 
It may have summered there, for a late spring male was also seen 4 June 1983; these are the only two records of scoters at McArthur Falls.

The latest recent fall record was a lone male at Natalie Lake just before freeze-up 25 November 1984. There is one old winter record; a bird was rescued from the ice on the Assiniboine River in Winnipeg by Kenneth Lang 9 January 1925. It was forwarded to H.M. Speechly and later released. ${ }^{13}$

Full information is not available on the plumages of fall White-winged Scoters because distinction in the field at long range is often difficult, but adult males sometimes predominate, e.g. 14 of 16 birds at Natalie Lake 24 October 1982.

\section{Miscellaneous Observations}

Nearly all of these scoters were seen resting and feeding on large lakes. Although some pause for less than a day, others appear to remain for a week or more before continuing their migration. Some authorities assert that migrating scoters do not feed on inland stopovers. ${ }^{15}$ On the contrary we have observed all three species actively feeding at Natalie Lake and elsewhere. The exact attraction of Natalie Lake is not clear. Its maximum depth is $30 \mathrm{~m}$, little more than several other stretches of the Winnipeg River that do not attract large numbers of diving birds.

There are three records of White-winged Scoters apparently migrating along the Winnipeg River. At about 8 p.m. 5 May 1977 all but one of a flock of 13 left the lake and flew northward (downstream); only one was seen the following day. At about 8 a.m. 20 May 1984 groups of two and seven birds flew downstream past Seven Sisters dam. At 11 a.m. 14 October 1985 five left Natalie Lake, steadily gained altitude and disappeared to the east (upstream).
Although scoters usually occur on large bodies of water, all three species have been seen at sewage lagoons. A Black Scoter was at the Pinawa lagoons 5 November 1977. Two Surfs were at Pinawa lagoons 2-5 October 1983 and two more at the Steinbach lagoons 29 September 1984 (Dennis Fast). One White-winged Scoter was at the Lac du Bonnet lagoons 5 November 1980 and there are three records at the Charleswood sewage lagoons in Winnipeg: four birds 19 and 26 October 1980 and three 4 November 1979 (Holland).

\section{Discussion}

Based on these records, the Black Scoter is an accidental spring migrant, but rare and probably regular in fall in southeastern Manitoba. The Surf Scoter is rare and irregular in spring and rare to locally uncommon, albeit erratic, in fall. The White-winged Scoter is rare to locally uncommon and regular in both seasons. This probably represents the southern fringe of a broad movement of scoters across the boreal forest, between the Atlantic Coast and points northwest of the study area.

There are no clear-cut differences in the distribution of records of the three species (Fig. 1). All three have been seen at six locations and two have been seen at another five, out of a total of 17 .

The higher frequency of Surf and Black Scoters in fall than spring suggests that some move south on Lakes Manitoba and Winnipeg, and funnel southeastward along the Winnipeg River. The scarcity of records on the Red River which flows north into Lake Winnipeg is noteworthy. Larger numbers might occur far offshore on the large lakes, then leave the province at high altitude. The best time to search for such concentrations is probably the first half of October, although moulting flocks of White-winged Scoters formerly occurred far out on Lake Manitoba in late July. 17 
The increased frequency of Surf and Black Scoter records since 1975 is certainly due in part to increased observer interest and effort, but it may also reflect an absolute increase. The large number of Surf Scoters seen since 1982 seems to be part of a wider phenomenon, judging from records in many parts of North America as reported in American Birds (see in particular vol. 39, no. 1, 1985).

\section{Acknowledgements}

We are grateful to the many observers cited above and to Reto Zach and Howard Ross for helpful comments on the manuscript.

1 BELLROSE, F.C. 1976. Ducks, geese and swans of North America. Stackpole Books, Harrisburg, Pa. 544 pp.

2 CLEVELAND, N.J., G.D. GRIEEF, G.E. HOLLAND, P.A. HORCH, R.W. KNAPTON, R.F. KOES and W.D. KYLE 1978. Field check-list of the birds of southeastern Manitoba. Manitoba Naturalists Society, Winnipeg.

3 FAANES, C.A. 1981. Recent scoter brood observations at Churchill, Manitoba. Blue Jay 39:223-224.

4 GARDNER, K.A 1981. Birds of Oak Hammock Marsh Wildlife Management Area. $172 \mathrm{pp}$. (Available from Manitoba Museum of Man and Nature, Winnipeg.)

5 GODFREY, W.E. 1986. The birds of Canada, revised edition. Natl. Mus. Can., Ottawa. $595 \mathrm{pp}$.

6 HATCH D.R.M. 1974. White-winged Scoters may be increasing. Chickadee Notes, Winnipeg Free Press, 24 August 1974.

7 HOCHBAUM, H.A. 1944. The Canvasback on a prairie marsh. North Amer. Wildl. Inst., Washington, D.C. 201 pp.

8 HOCHBAUM, H.A. 1955. Travels and traditions of waterfowl. Univ. of Minn. Press,
Minneapolis (reprinted in paperback, 1967). $301 \mathrm{pp}$.

9 HOCHBAUM, P.W. 1971. The Delta marsh. Man. Dept. of Mines, Resources and Environmental Management, Winnipeg. 52 pp.

10 HOUSTON, C.S. and P.W. BROWN 1983. Recoveries of Saskatchewan-banded Whitewinged Scoters, Melanitta fusca. Can. FieldNat. 97:454-455.

11 JEHL, J.R. Jr. and B.A. SMITH 1970. Birds of the Churchill region, Manitoba. Special Publ. No. 1, Manitoba Mus. Man and Nat., Winnipeg. $87 \mathrm{pp}$.

12 KNAPTON, R.W., R.F. KOES and P. TAYLOR 1978. Rare waterfowl in southern Manitoba, 1977. Blue Jay 36:214-215.

13 LAWRENCE, A.G. 1925. Chickadee Notes, 199 and 200, Winnipeg Free Press, 15 and 22 January 1925.

14 LAWRENCE, A.G. 1926. Chickadee Notes, 265, Winnipeg Free Press, 22 April 1926.

15 PALMER, R.S., Editor 1976. Handbook of North American Birds, Vol. 3. Yale Univ. Press, New Haven \& London. 560 pp.

16 ROSS, R.K. 1983. An estimate of the Black Scoter, Melanitta nigra, population moulting in James and Hudson bays. Can. Field-Nat. 97:147-150.

17 STEWART, R.E. 1975. Breeding birds of North Dakota. Tri-College Center for Environmental Studies, Fargo, N.D. 295 pp.

18 TAYLOR, P. 1985. Wings along the Winnipeg: the birds of the Pinawa - Lac du Bonnet region, Manitoba. (reprinted with supplement and minor corrections). Eco Series No. 2, Man. Nat. Soc., Winnipeg. 223 pp.

19 THOMPSON, E.E. 1891. The birds of Manitoba. Proc. U.S. Natl. Mus. 13:457-643. Reprinted in "Ernest Thompson Seton in Manitoba, 1882-1892." Premium Ventures and Man. Nat. Soc., Winnipeg. 1980. 